\title{
KONSTRUKSI HUKUM PERLINDUNGAN ADHERED PARTY DALAM KONTRAK ADHESI YANG DIGUNAKAN DALAM TRANSAKSI BISNIS
}

\author{
Faizal Kurniawan \\ Ayik Parameswary \\ Fakultas Hukum Universitas Airlangga Surabaya \\ e-mail: faizal@fh.unair.ac.id
}

\begin{abstract}
ABSTRAK
Prinsip kebebasan berkontrak membawa para pihak dalam suatu kontrak untuk menandatangani suatu persetujuan, termasuk diantaranya adalah kontrak baku. Kontrak baku dibuat oleh satu pihak, biasanya oleh suatu perusahaan dengan tujuan adanya efisiensi. Kontrak tersebut bagaimanapun berpotensi adanya penyalahgunaan kedudukan yang lebih mendominasi dalam penerapannya, kontrak seperti ini dikenal dengan nama kontrak adhesi. Dalam kaitannya dengan kontrak adhesi terdapat batasan dan/atau pengalihan tanggung jawab dari resiko bisnis kepada mitra berkontraknya (adhered party). Maka dari itu prinsip itikad baik tentu memainkan peranan yang cukup penting untuk mengevaluasi implementasi dari kontrak adhesi. Penulisan ini membahas kontrak adhesi dalam kaitannya dengan prinsip dasar hukum kontrak dan juga menganalisa payung hukum untuk mitra berkontraknya (adhered party) dalam pencarian hak-hak kontraktualnya terkait implementasi dari kontrak adhesi. Dalam tulisan ini juga akan dibandingkan implementasi dari kontrak adhesi dalam prakteknya baik di Indonesia dan di luar Indonesia dengan cara menganalisa hukum nasional dan aturan yang berlaku secara internasional seperti Prinsip-prinsip Kontrak Perdagangan Internasional (The Principles of International Comercil Contracts-PICC).
\end{abstract}

Kata Kunci: kontrak adhesi, itikad baik, penyalahgunaan kekuasaan.

\begin{abstract}
Freedom of contract principle brings the contracting parties to sign into an agreement in such forms, including a standard contract. The standard contracts are made by one party, usually by business entities in the aim of doing efficiency. The contracts, however, potentially contains abuse of power in its application, known as adhesion contract. In term of adhesion contract, it contains prompt restrictions and/or transfer of responsibilities of the business risks to the adhered party. Therefore, good faith principle plays an important role to evaluate the implementation of the adhesion contract. This article discusses the adhesion contract in the light of the basic principles in contract law and explores the legal frameworks for adhered party to seek their contractual rights in conjunction with the implementation of the adhesion contract. We also compare the implementation of the adhesion contract, practically, both in Indonesia and international practices by examining the national laws and the model law e.g. Principles of International Commercial Contracts (PICC).
\end{abstract}

Keywords: Adhesion contract, good faith, abuse of power.

\section{PENDAHULUAN}

Bisnis komersial merupakan suatu bidang dalam kehidupan yang banyak memberikan kontribusi bagi pemenuhan maupun peningkatan perekonomian masyarakat melalui serangkaian kegiatan yang menuntut hubungan timbal balik antara manusia. Semakin berkembangnya jaman diiringi semakin meningkatnya taraf hidup masyarakat, semakin besar pula tuntutan pemenuhan kebutuhan manusia untuk 
keberlangsungan hidup mereka sehari-hari. Situasi demikian membuat manusia saling berinteraksi dengan manusia yang lainnya untuk mengisi kebutuhan mereka dari nilai guna suatu barang maupun jasa.

Disadari atau tidak, hubungan para pihak yang terjalin dalam aktivitas bisnis komersial tersebut juga akan diikuti oleh kesepakatan-kesepakatan untuk membangun aturan-aturan yang akan menjadi dasar pelaksanaan aktifitas tersebut yang harus dipatuhi bersama oleh para pihak untuk mencapai tujuannya. Dari adanya kesepakatan untuk membangun ketentuan atau aturan tersebut, lahirlah apa yang dinamakan dengan kontrak atau perjanjian. Kontrak atau perjanjian tersebut mengandung hubungan kontraktual di antara para pihak yang diwujudkan melalui pelaksanaan kewajiban oleh para pihak yang membentuk dan melaksanakan perjanjian tersebut. Beranjak dari adanya hak dan kewajiban inilah pentingnya hukum hadir untuk memberikan pengaturannya karena eksistensi hukum itu sendiri sangat erat dengan perlindungan hak manusia dan keadilan.

Bila melihat dari tata cara pembentukannya (law making process), hukum perdata lahir dari dua kewenangan pembentukan hukum, yaitu kewenangan kewenangan pembentukan hukum yang dimiliki oleh negara (Lembaga Eksekutif bersama dengan Lembaga Legislatif atau DPR) (Lebih jauh lihat Undang-Undang No. 12 Tahun 2011 tentang Pembentukan Peraturan Perundang-undangan, serta Pasal 5, 20 dan 21 UUD 1945), serta juga kewenangan pembentukan hukum yang dimiliki oleh setiap warga negara.

Kewenangan pembentukan hukum yang dimiliki oleh negara memberikan konsekuensi lahirnya hukum yang demi hukum (by law) akan berlaku dan mengikat seluruh warga Negara yang tunduk padanya terhitung sejak hukum tersebut diberlakukan. Sementara kewenangan pembentukan hukum yang dimiliki oleh setiap warga merupakan kewenangan masingmasing pihak (party authonomy) yang pada dasarnya lahir dari pelaksanaan prinsip kebebasan berkontrak (freedom of contract) yang harus dipatuhi berdasarkan asas Pacta Sunt Servanda, dimana keberlakuan dari hukum yang diciptakan oleh masing-masing warga negara tersebut hanyalah mengikat sebagai hukum di antara pihak-pihak yang setuju untuk terikat padanya (contracting parties).

Kewenangan pembentukan hukum oleh para pihak menghasilkan suatu produk hukum yang dikenal dengan nama kontrak atau perjanjian, yang kemudian mengikat bagi para pihak yang membuatnya tersebut layaknya sebagai undang-undang. Keberlakuan kontrak atau perjanjian sebagai undang-undang yang mengikat dan harus dipatuhi oleh yang membuatnya, secara eksplisit diatur Pasal 1338 Burgerlijk Wetboek (BW).

Disamping peraturan yang berlaku di dalam negeri, sebagai pedoman dalam pelaksanaan kegiatan bisnis komersial juga terdapat aturan yang berlaku secara internasional, mengingat seiring perkembangan zaman dan kemajuan teknologi kegiatan komersial kini sudah bergerak secara global tidak mengenal lintas batas negara (borderless). Hukum yang berlaku untuk mengatur prosedur kegiatan komersial secara internasional tersebut dikeluarkan oleh The International Institute for the Unification of Private Law (UNIDROIT), dengan menyusun dan mempublikasikan Prinsip-prinsip Kontrak Perdagangan Internasional (The Principles of International Comercial Contracs (Prinsip UNIDROIT atau PICC) pada bulan Juni 1994 (Ricardo Simanjuntak, 2011:18).

Permasalahan mulai muncul ketika adanya kontrak atau perjanjian ditetapkan secara sepihak oleh salah satu pihak yang lazimnya dilakukan oleh pelaku usaha, yang disebut dengan nama kontrak baku atau kontrak adhesi (standard contract) yang isi atau klausula dari perjanjian tersebut mengandung keadaan yang cenderung tidak fair bagi konsumen dengan pencantuman klausula yang bersifat membatasi kewajiban pelaku usaha dalam pelaksanaan perjanjian yang disebut dengan nama klausula eksonerasi.

Kontrak baku sendiri sebenarnya tidak dilarang karena merupakan perwujudan asas kebebebasan berkontrak namun dengan tidak adanya kesempatan bagi mitra berkontraknya untuk secara face to face dapat menegosiasikan poin-poin kesepakatan yang diinginkan ataupun diterimanya sehubungan dengan transaksi ataupun perbuatan hukum yang akan mereka lakukan, membuat posisi mitra berkontraknya secara langsung ataupun tidak langsung seolah-olah cenderung terpaksa, dimana keadaan mitra berkontraknya tersebut terdesak oleh tingkat kebutuhan, sehingga tidak mempunyai pilihan lain kecuali menandatangani kontrak yang sebenarnya mengandung kelemahan pada hak hukumnya. Menjadi suatu persoalan, apakah hal ini merupakan bentuk pelanggaran terhadap prinsip kebebasan berkontrak sebagaimana ditegaskan dalam Pasal 1338 BW dan Undang-Undang Nomor 8 Tahun 1999 tentang Perlindungan Konsumen maupun Hukum Kontrak Internasional (PICC). 
Berdasarkan pendahuluan di atas, maka isu hukum yang diangkat adalah prinsip-prinsip hukum kontrak dalam pembentukan dan pelaksanaan kontrak adhesi dan kekuatan mengikat kontrak adhesi, serta analisis yuridis putusan pengadilan terkait penerapan kontrak adhesi dalam transaksi bisnis.

\section{PEMBAHASAN}

\section{Prinsip Freedom of Contract dalam Tahap Pembentukan Kontrak Adhesi}

Perjanjian atau kontrak yang mengikat sebagai hukum bagi para pihak yang membuatnya, disamping hukum atau peraturan yang lahir dari peraturan perundang-undangan atau produk perundang-undangan pemerintah, lahir dari pembentukan hukum yang dimiliki oleh setiap warga negara (party authonomy) yang pada dasarnya dilakukan dengan pelaksanaan prinsip kebebasan berkontrak (freedom of contract) yang harus dipatuhi berdasarkan asas Pacta Sunt Servanda, dimana keberlakuan dari hukum yang diciptakan oleh masing-masing warganegara tersebut hanyalah mengikat sebagai hukum di antara pihakpihak (contracting parties) yang setuju untuk terikat padanya. Keberlakuan perjanjian sebagai undang-undang yang mengikat dan harus dipatuhi para pihak yang membuatnya secara eksplisit diatur dalam Pasal 1338 BW, yang menerangkan bahwa segala perjanjian yang dibuat secara sah, berlaku sebagai undang-undang bagi mereka yang membuatnya.

Salah satu wujud dari asas kebebasan berkontrak ini adalah dalam kegiatan bisnis komersial banyak kalangan pelaku usaha menutup transaksi dengan terlebih dahulu telah menyiapkan format-format kontrak yang umumnya telah tercetak (printed contract) untuk ditandatangani oleh mitra berkontraknya, baik secara langsung maupun tidak langsung. Inilah yang disebut dengan kontrak baku, yang berasal dari terjemahan dari bahasa Inggris, yaitu standard contract. Kontrak baku (standard contract) merupakan perjanjian yang telah ditentukan dan dituangkan dalam bentuk tercetak secara sepihak (satu arah) oleh salah satu pihak, yaitu pihak yang menduduki ekonomi lebih kuat atau pengetahuan akan objek perjanjian yang lebih besar daripada mitra berkontraknya atau konsumen. Kontrak baku disebut juga dengan kontrak adhesi (contract of adhesion), karena apa yang ada dalam perjanjian baku sama bentuknya dengan kontrak adhesi yaitu berupa formulir-formulir yang dibuat oleh salah satu pihak sudah lekat tidak dapat diubah-ubah lagi, maka pihak lainnya tinggal menandatanganinya saja. Adapun kecenderungan pihak yang menetapkan kontrak baku untuk membuat kontrak baku dalam melaksanakan kegiatan komersial dilatar belakangi oleh beberapa faktor, yaitu: (Ricardo Simanjuntak, 2011:207)

Pertama, Posisi dan pengetahuan dari para pelaku usaha terhadap hal-hal yang diperjanjikan tersebut yang lebih kuat dan dominan, yang membuat posisi mitra berkontraknya secara langsung atau pun tidak langsung cenderung dipaksa, dimana keadaan mitra berkontraknya tersebut juga terdesak oleh tingkat kebutuhan, sehingga tidak mempunyai pilihan lain kecuali menandatangani kontrak yang sebenarnya banyak mengandung kelemahan pada hak hukum mitra berkontraknya tersebut.

Kedua, Beberapa kalangan juga berpendapat bahwa, pertumbuhan kuantitas, kualitas termasuk kompleksitas aktivitas bisnis yang didukung oleh wilayah jangkauan pasar atau pelayanan yang sudah semakin tanpa batas (borderless) serta dukungan teknologi yang semakin canggih membuat dunia bisnis, tidak saja pelaku usaha, produsen atau pun pedagang akan tetapi juga termasuk pembeli atau pengguna jasa, cenderung semakin menghindar bentuk-bentuk atau pun proses-proses berbisnis yang efisien dan tidak bertele-tele yang dalam beberapa hal dapat menjadi keunggulan komparatif dari perusahaan-perusahaan tersebut dalam melayani para mitra berkontraknya.

Dalam kaitannya dengan kontrak baku, prinsip kebebasan berkontrak baik yang terdapat pada PICC maupun BW menyentuh pada beberapa aspek, yaitu dalam penentuan isi atau klausula kontrak, dimana pada kontrak baku, isi atau klausula kontrak telah ditentukan terlebih dahulu secara sepihak oleh pelaku usaha, sehingga kecil kemungkinan atau bahkan tidak ada negosiasi bagi konsumen untuk turut menentukan poin-poin kesepakatan yang diinginkannya secara langsung (face to face). Hal ini merupakan bentuk pembatasan prinsip kebebasan berkontrak dalam hal pembentukan perjanjian bagi para pihak yang membuatnya.

Dengan pernyataan di atas, maka secara langsung maupun tidak langsung keberadaan kontrak baku seolah bagaikan pisau bermata dua terhadap prinsip kebebasan berkontrak, yakni dimana pembentukan kontrak baku itu sebenarnya tidak dilarang atas dasar prinsip kebebasan berkontrak, namun di sisi lain kontrak baku telah membatasi bahkan menghilangkan prinsip kebebasan berkontrak itu sendiri dengan tidak adanya 
ability bagi mitra berkontraknya untuk secara face to face dapat menegosiasikan poin-poin kesepakatan yang diinginkannya.

\section{Prinsip Itikad Baik (Good Faith) dalam Pembentukan Kontrak Baku}

Prinsip kedua menyangkut tindakan-tindakan yang dilakukan dengan itikad buruk (Bad Faith) secara sepihak oleh pelaku usaha untuk membangun klausula eksonerasi sebagai suatu upaya untuk menjaga dirinya dari pembebanan kewajiban yang mungkin muncul dari pelaksanaan perjanjian tersebut. Untuk melancarkan pelaksanakan maksudnya tersebut, pelaku usaha cenderung akan mencetak klausula kontrak tersebut dengan huruf-huruf yang sangat kecil dengan warna cetakan berwarna kuning misalnya, sehingga sangat sulit untuk dibaca oleh para konsumen atau mitra berkontraknya.

Syarat itikad baik ini diatur dalam Pasal 1338 ayat (3) BW dan pada PICC diatur dalam Pasal 1.7 dan 2.15 yang menekankan perlunya itikad baik dan kejujuran (good faith and dealing) dan melarang adanya proses pembentukan kontrak yang didasari itikad buruk. Itikad baik hendaknya diartikan dan diformulasikan pada seluruh proses kontrak (Agus Yudha Hernoko, 2010:143).

\section{Prinsip Konsensualisme dalam Pencapaian Kesepakatan pada Kontrak Baku}

Disepakatinya kontrak baku oleh adhered party karena terdesak oleh kebutuhan sehingga tidak ada pilihan lain, merupakan kesepakatan yang diberikan seolah-olah secara terpaksa. Meskipun demikian, jika kita kembali menelaah unsur pembentukan kontrak baku itu sendiri yang merupakan hasil kewenangan secara sepihak oleh pihak yang mempunyai posisi lebih kuat dalam hal pengetahuan tentang objek perjanjian, maka seharusnya yang mampu mengontrol pemenuhan kebutuhan mitra berkontrak adalah pihak yang membuat kontrak baku itu sendiri. Hal demikian merupakan bentuk dari adanya penyalahgunaan keadaan (misbruik van omstandigheden) yang mana terjadi hilangnya kebebasan dari mitra berkontrak dalam menyepakati kontrak baku.

\section{Asas Keseimbangan sebagai Dasar Perlindungan Hukum Adhered Party}

Dalam hal terjadi ketidakseimbangan posisi yang menimbulkan gangguan terhadap isi kontrak diperlukan otoritas pemerintah (Agus Yudha Hernoko, 2010:143). Keadaan demikian sangat relevan kita jumpai pada penerapan kontrak baku yang dibuat oleh pelaku usaha kepada mitra berkontraknya yang berkedudukan sebagai konsumen. Hubungan antara produsen-konsumen sendiri diasumsikan sebagai hubungan subordinat sehingga konsumen berada pada posisi lemah dalam proses pembentukan kehendak kontraktualnya.

Tujuan dari asas keseimbangan adalah hasil akhir yang menempatkan posisi para pihak seimbang (equal) dalam menentukan hak dan kewajibannya. Oleh karenanya otoritas negara diperlukan dalam rangka menyeimbangkan posisi para pihak, yaitu pelaku usaha dan konsumen, dengan dikeluarkannya UndangUndang Nomor 8 Tahun 1999 tentang Perlindungan Konsumen (Agus Yudha Hernoko, 2010:80).

Pertama, Kekuatan Mengikat klausula Baku dalam Pelaksanaan Kontrak. Hal yang memberi kekuatan mengikat pada isi atau klausula dalam kontrak baku yang muncul dari asas kebebasan berkontrak tersebut adalah keabsahan dibuatnya kontrak tersebut sebagaimana diatur dalam Pasal 1320 BW, yaitu: a. Kesepakatan (konsensualisme) sebagaimana telah dikemukakan pada bagian sebelumnya bagaimana eksistensi kesepakatan dalam kontrak baku; b. Syarat itikad baik sebagaimana diatur dalam Pasal 1338 ayat (3) KUH Perdata maupun Pasal 1.7 dan 2.15 PICC (Agus Yudha Hernoko, 2010:129). Hal ini juga berlaku pada pembentukan kontrak baku yakni menyangkut klausula kontrak, seperti tidak mencantumkan klausulaklausula eksonerasi yang memberikan posisi tidak patut bagi konsumen; c. Kesesuaian pernyataan dengan putusan kehendak itu dapat dinilai dari timbulnya kepercayaan yang wajar atau objektif dari pihak lain (pelaku usaha) dari pernyataan yang diberikan oleh konsumen tersebut.

Kedua, Tinjauan Yuridis dari Kontrak Baku berdasarkan Prinsip UNIDROIT (PICC). Tinjauan yuridis kontrak baku berdasarkan Procedure of International Commercial Contract (PICC) atau Prinsip UNIDROIT, menitikberatkan pada prinsipprinsip umum mengenai hukum kontrak yang kemudian menjadi referensi hukum bagi beberapa negara yang telah meratifikasinya, guna menciptakan harmonisasi pengaturan mengenai kontrak bisnis komersial di antara negara-negara yang ingin menerapkannya tersebut.

Tujuan itu dicapai dengan mengakomodasi prinsipprinsip yang dijadikan menjadi prinsip umum bagi 
kontrak komersial internasional yang ditutup oleh pelaku bisnis internasional. Prinsip-prinsip umum tersebut dapat ditetapkan ke dalam aturan hukum domestik suatu negara tetapi juga dipakai oleh pelaku bisnis antar negara untuk kontrak mereka (Emmy Pangaribuan Simanjuntak, 2010:1) sehingga tinjauan yuridis kontrak baku dalam Procedure of International Commercial Contract (PICC) atau Prinsip UNIDROIT merupakan hal yang penting karena prinsip dalam konvensi inilah yang kemudian menjadi dasar bagi pengembangan hukum kontrak di suatu negara sebagaimana yang telah dilakukan oleh Belanda dalam code civilnya (Nieuw burgerlijk Wetboek atau NBW). Prinsip UNIDROIT merupakan prinsip hukum yang mengatur hak dan kewajiban para pihak pada saat mereka menerapkan prinsip kebebasan berkontrak dalam membuat kontrak karena prinsip kebebasan berkontrak jika tidak diatur bisa membahayakan pihak yang lemah.

Pengaturan mengenai kontrak baku (standard contract) dalam PICC terdiri dari empat substansi yang termuat dalam Article 2.19 (Contracting under standard terms) menyatakan bahwa: Where one party or both parties use standard terms in concluding a contract, the general rules on formation apply; Standard terms are provisions which are prepared in advance for general and repeated use by one party and which are actually used without negotiation with the other party. dan juga diatur dalam Article 2.20 (Surprising terms) menyatakan bahwa: No term contained in standard terms which is of such a character that the other party could not reasonably have expected it, is effective unless it has been expressly accepted by that party; In determining whether a term is of such a character regard shall be had to its content, language and presentation. Serta dalam Article 2.21 (Conflict between standard terms and non-standard terms) menyatakan bahwa In case of conflict between a standard term and a term which is not a standard term the latter prevails; Article 2.22 (Battle offorms) menyatakan bahwa Where both parties use standard terms and reach agreement except on those terms, a contract is concluded on the basis of the agreed terms and of any standard terms which are common in substance unless one party clearly indicates in advance, or later and without undue delay informs the other party, that it does not intend to be bound by such a contract.

PICC memberikan pengertian kontrak baku, sebagaimana termuat dalam Article 2.19, sebagai ketentuan standar yang dipahami sebagai ketentuanketentuan kontrak yang dipersiapkan sebelumnya untuk penggunaan umum dan berulang-ulang oleh salah satu pihak dan yang benar-benar digunakan tanpa negosiasi dengan pihak lain sehingga dapat diuraikan unsur-unsur kontrak baku berdasar PICC adalah: Telah dipersiapkan sebelumnya; Digunakan untuk penggunaan umum dan berulang; Ditentukan oleh salah satu pihak; serta, Digunakan tanpa negosiasi dengan pihak lainnya.

PICC memberikan gambaran yang luas mengenai ruang lingkup kontrak baku berdasar pada unsur-unsur yang mengikuti kontrak baku, yakni menyangkut penyajian atau presentasi formalitas serta siapa yang mempersiapkan kontrak tersebut secara terlebih dahulu. Artinya, seperti apapun kontrak baku tersebut dituangkan, misalnya apakah termuat dalam dokumen terpisah atau terintegrasi dalam dokumen kontrak itu sendiri, apakah dikeluarkan melalui formulir pracetak (draft kontrak), atau bahkan ada pada komputer secara online yang biasanya dilakukan dalam perdagangan melalui internet (e-commerce) serta oleh siapa pun pihak yang mempersiapkannya, yakni para pihak dalam atau di luar kegiatan perdagangan, atau pun asosiasi profesi. Selama kontrak tersebut telah memenuhi unsur-unsur tersebut, maka sudah dapat dikategorikan sebagai kontrak baku.

Batasan penerapan kontrak baku dituangkan dalam Article 2.20 UNIDROIT yang mengatur bahwa terhadap persyaratan atau klausul standar yang terdapat dalam kontrak baku dapat dinyatakan tidak berlaku atau kehilangan daya ikatnya apabila persyaratan tersebut tidak dapat secara layak diharapkan oleh suatu pihak, kecuali pihak tersebut secara tegas menerimanya. Artinya, ketika kontrak baku yang telah ditetapkan salah satu pihak tersebut mengandung klausula yang menimbulkan posisi yang sangat tidak patut bagi mitra berkontraknya (klausula eksonerasi), maka kontrak tersebut dapat dinyatakan tidak berlaku. Hal ini dapat dilakukan oleh pihak yang tertindas tersebut melalui gugatan pembatalan kontrak ke pengadilan sesuai alasan tersebut dan keadaan ini dikecualikan atau kontrak tetap berlaku apabila pihak tersebut menerima secara tegas kontrak tersebut meskipun menimbulkan posisi yang merugikan pada dirinya.

Untuk menentukan apakah suatu persyaratan memenuhi ciri seperti tersebut di atas akan bergantung pada isi, bahasa, dan penyajiannya. Misalnya pada kontrak baku yang bermaksud membuat jebakan 
terhadap mitra berkontraknya dengan memuat klausula eksonerasi sebagai upaya untuk menjaga dirinya dari pembebanan kewajiban yang mungkin muncul dari pelaksanaan perjanjian tersebut dengan mencetaknya dengan huruf yang sangat kecil dengan warna cetakan kuning misalnya, sehingga sulit untuk dibaca atau meletakkan klausula tersebut pada tempat tersembunyi sehingga cenderung tidak dibaca oleh pihak lain.

Terkait dengan definisi kontrak baku pada Pasal 2.19 yang menyatakan bahwa kontrak baku dipersiapkan sebelumnnya oleh salah satu pihak tanpa melalui proses negosiasi terlebih dahulu dengan pihak lainnya. Adakalanya menghadapi situasi demikian pihak lain yang akan mengikatkan diri dalam kontrak tersebut dengan melakukan negosiasi terlebih dahulu untuk menyetujui klausula-klausula (terms) kontrak baku tersebut sehingga melahirkan ketentuan atau klausula baru dalam kontrak yang mewakili kepentingan mereka juga. Dengan demikian terdapat dua jenis klausula dalam kontrak tersebut, yakni klausula baku (standard terms) yang telah dipersiapkan sebelumnya oleh salah satu pihak serta klausula hasil negosiasi dengan pihak yang akan mengikatkan diri dalam kontrak, yang mewakilkan kepentingannya dalam klausula tersebut terhadap substansi yang sama. Atas keberadaan dua klausula yang memiliki sifat bertentangan ini, klausula hasil negosiasi para pihak tersebut akan "menang" atas klausula baku yang bertentangan atau merugikan posisi pihak yang mengikuti kontrak tersebut karena klausula hasil negosiasi tersebut lebih mungkin untuk mengakomodir atau mencerminkan maksud dari para pihak.

Hal ini lazimnya terjadi pada kontrak baku yang dituangkan dalam bentuk formulir pracetak (draft kontrak), yang masih memungkinkan dilakukannya negosiasi oleh para pihak. Adanya klausula baku yang terlebih dahulu telah ada dan klausula baru hasil negosiasi ini disebut dengan conflict between standard terms and non-standard terms, sebagaimana diatur dalam Pasal 2.21.

Masih terkait mengenai konflik norma dalam kontrak baku, Pasal 2.22 PICC mengakomodir untuk suatu keadaan dimana jika kedua belah pihak telah sepakat untuk menggunakan kontrak baku, namun juga membuat suatu kontrak berdasarkan perjanjian yang telah disepakati (non standard contract) untuk mengecualikan keberlakuan persyaratan-persyaratan dalam kontrak baku tertentu yang memiliki kesamaan dalam substansi. Maka kedua kontrak ini (standard contract dan non standard contract) berlaku kecuali suatu pihak sebelumnya telah menyatakan jelas atau kemudian tanpa penundaan untuk memberitahukannya kepada pihak lain, bahwa hal tersebut tidak dimaksudkan untuk terikat dengan kontrak tersebut.

Hal ini berarti untuk memberi kepastian hukum terkait kapan kontrak baku (standard contract) itu berlaku serta klausula-klausula mana yang mengikat dalam kontrak tersebut, yakni ditandai dengan adanya kesepakatan kedua belah pihak yang berkontrak berdasarkan kehendaknya untuk menyetujui persyaratan atau klausula baku mana saja dalam kontrak baku tersebut yang berlaku dengan menyepakati perjanjian lain (non standard contract) yang memiliki persamaan substansi sehingga mereka mencapai kesepakatan, dan mulai saat itu berlakulah kontrak baku tersebut berdasarkan perjanjian yang telah disepakati. Namun hal tersebut tidak berlaku ketika salah satu pihak dalam kontrak tersebut telah memberitahukan atau mengumumkan baik kepada mitra berkontraknya maupun kepada orang lain (pihak ke-3) bahwa ketentuan atau klausula standard tersebut memang tidak dimaksudkan untuk diberlakukan.

Keadaan demikian disebut dengan Battle of Form karena konflik yang terjadi bukan menyangkut klausula dalam kontrak melainkan antara bentuk kontrak yang berbeda (standard contract \& non standard contract).

Ketiga, Perbandingan Sistematika PICC dengan BW dan Undang-Undang Nomor 8 Tahun 1999. Apabila kita membandingkan substansi pengaturan kontrak baku dalam PICC, BW dan Undang-Undang Nomor 8 Tahun 1999 maka akan diperoleh gambaran sebagaimana Tabel 1.

Keempat, Pencantuman Jenis Klausula Baku pada Kontrak. Penerapan kontrak baku juga dapat dibedakan dalam kontrak konsumen (kontrak adhesi) dengan kontrak baku pada kontrak bisnis. Terkait perbedaan lingkup penerapan kontrak baku yang demikian tentu hal ini merujuk pada dasar hukum yang melatarbelakangi keabsahan pencantuman klausula pembebasan atau pembatasan tanggung jawab (klausula eksonerasi) yang mana pada kontrak konsumen hal ini secara tegas dilarang berdasarkan ketentuan dalam Pasal 18 UU Perlindungan Konsumen sedangkan penerapan pada kontrak bisnis hal pencantuman klausula pembatasan tanggung jawab diperbolehkan berdasarkan Pasal 1493 BW diikuti batasannya pada Pasal 1494 BW. 
Tabel 1. Perbandingan Sistematika Pengaturan Klausula Baku dalam PICC , BW dan Undang-Undang Nomor 8 Tahun 1999

\begin{tabular}{|c|c|c|c|}
\hline Substansi & Prinsip Unidroit/PICC & UU No. 8 Tahun 1999 & BW \\
\hline Asas terkait kontrak baku & $\begin{array}{l}\text { Consensualism, } \\
\text { freedom of contract, } \\
\text { good faith and dealing }\end{array}$ & $\begin{array}{l}\text { Keadilan, keseimbangan, } \\
\text { kepastian hukum }\end{array}$ & $\begin{array}{l}\text { Kebebasan berkontrak, iktikad } \\
\text { baik, konsensualisme }\end{array}$ \\
\hline Definisi klausula baku & Pasal 2.19 & Pasal 1 angka 10 & - \\
\hline Lingkup kontrak & $\begin{array}{l}\text { Kontrak baku di dalam atau } \\
\text { luar kegiatan perdagangan, } \\
\text { asosiasi profesi }\end{array}$ & $\begin{array}{l}\text { Kontrak baku dalam } \\
\text { kontrak konsumen }\end{array}$ & $\begin{array}{l}\text { Semua perjanjian yang lahir dari } \\
\text { prinsip freedom of contract dan } \\
\text { memenuhi Pasal } 1320 \mathrm{BW}(1338 \\
\text { jo } 1320 \mathrm{BW})\end{array}$ \\
\hline $\begin{array}{l}\text { Klausula yang dilarang atau } \\
\text { pembatasan tanggung jawab }\end{array}$ & Pasal $2.20(1)$ & Pasal 18 ayat (1) & Pasal 1493-1494 BW \\
\hline $\begin{array}{l}\text { Konflik norma } \\
\text { antara klausula } \\
\text { dalam kontrak }\end{array}$ & Pasal 2.21 & Tidak diatur & - \\
\hline Surprising Terms & Pasal $2.20(2)$ & Pasal 18 ayat (2) & - \\
\hline $\begin{array}{l}\text { Tanggung jawab pelaku } \\
\text { usaha }\end{array}$ & Tidak diatur & Pasal 19-28 & - \\
\hline Upaya Hukum adhere party & $\begin{array}{l}\text { Gugatan pembatalan } \\
\text { kontrak ke pengadilan atas } \\
\text { dasar adanya surprising } \\
\text { term (Pasal } 2.20)\end{array}$ & $\begin{array}{l}\text { Gugatan ke Pengadilan } \\
\text { atau diluar pengadilan atas } \\
\text { dasar PMH (Pasal 45) }\end{array}$ & $\begin{array}{l}\text { Pemutusan perjanjian atas dasar } \\
\text { wanprestasi } \\
\text { (Pasal } 1266 \mathrm{BW}) \text {, Pembatalan } \\
\text { keabsahan perjanjian (Pasal } 1338 \\
\text { jo } 1320 \mathrm{BW} \text { ) }\end{array}$ \\
\hline
\end{tabular}

Sumber: dari PICC, BW dan Undang-Undang Nomor 8 Tahun 1999

Sengketa terkait penerapan kontrak baku sebagaimana yang terjadi di Amerika Serikat pada tahun 1873 (R.R.v. Lockwood, (1873:357), ketika adanya klausula eksonerasi dalam bill of lading yang membatasi kewajiban pelaku usaha (carriers). Terhadap sengketa ini, The United States Supreme Court menekankan pada konsensualisme yang telah terjadi terhadap perjanjian tersebut. Contoh lain terkait kecenderungan digunakannya kontrak standar dalam transaksi bisnis komersial adalah pada perjanjian asuransi yang dikeluarkan oleh perusahaan asuransi, perjanjian kredit (loan) dengan penerbitan surat bukti kredit yang mengikat setelah ditandatangani oleh para pihak berdasarkan ketentuan yang berlaku pada lembaga tersebut. Lain halnya dengan kontrak baku berbentuk draft yang masih dimungkinkan dilakukan negosiasi untuk perubahan klausula-klausulanya, terdapat pula bentuk kontrak baku dalam kontrak konsumen lainnya yang tidak lagi dapat dikatakan sebagai draft yang masih dapat diubah, melainkan sudah merupakan kontrak tercetak yang bahkan pada jenis tertentu tidak memerlukan lagi pernyataan persetujuan melalui langkah konvensional. Hal ini merupakan contoh lain dari klausula baku yang diwujudkan dalam dokumen perjanjian yang secara otomatis berlaku baik dikehendaki maupun tidak oleh konsumen dalam transaksi komersial. Klausula demikian dapat kita jumpai misalnya pada pembelian suatu barang yang pada nota atau struk (receipt) pembelian yang tertulis secara eksplisit bahwa "barang yang sudah dibeli tidak dapat dikembalikan". Hal demikian juga dapat kita jumpai pada klausula pembebasan tanggung jawab pada tiket parkir yang menyatakan bahwa pengelola parkir tidak bertanggungjawab sama sekali atas segala sesuatu yang terjadi terhadap mobil yang diparkir tersebut termasuk bila mobil tersebut hilang.

Kegiatan komersial lainnya yang juga tidak luput dari potensi penggunaan kontrak standar adalah perdagangan yang dilakukan dengan media internet atau lebih dikenal dengan istilah e-commerce. Seperti pada penggunaan perjanjian lisensi pengguna akhir (end user license agreements atau EULA) dalam jual beli perangkat lunak (software) melalui e-commerce yang menggunakan metode shrink wrap atau click wrap agreement (John Adams, 2004:1).

Permasalahan terkait penerapan shrinkwrap contract atau click wrap contract dalam jual beli software melalui e-commerce, yaitu seputar syaratsyarat dari kontrak tersebut yang telah ditetapkan satu arah oleh penjual yang dirasa unfair oleh adhered party karena kontrak tersebut tidak benar dan tidak mewujudkan kedudukan yang seimbang antara pelaku usaha dan adhered party. Salah satunya adalah syaratsyarat mengenai harus diturutinya beberapa hal yang 
dapat meliputi larangan untuk melakukan sesuatu dan jaminan terbatas (limited liability) dari penjual software atas produk yang dijualnya sehingga inilah yang disebut dengan perjanjian lisensi yang bernama EULA dengan mencantumkan klausula-klausula sebagai berikut: Pembatasan tanggung jawab (klausula eksenorasi); Klausula yang dimaksud untuk membatasi penggunaan informasi yang seharusnya sah di bawah hukum hak cipta nasional; Klausula yang terkait penegakan yurisdiksi ekslusif sebagai pemilihan forum dalam penyelesaian sengketa yang ditetapkan secara sepihak; dan Klausula penyelesaian sengketa melalui arbitrase yang bersifat mengikat dan ditetapkan secara sepihak (John Adams, 2004:1).

\section{Materi Muatan Putusan Mahkamah Agung Belanda Nomor C06/049HR}

Salah satu putusan pengadilan tentang penerapan kontrak baku adalah putusan yang dikeluarkan oleh Mahkamah Agung Belanda (Hoge Raad der Nederlanden/ HR) Nomor C06/049 tanggal 21 September 2007 (Unilex, "Unidroit Principle", www.unilex.info/case.cfm?id=1538). Isu-isu yang harus diputuskan pengadilan terkait sengketa ini antara lain, apakah pembeli telah menerima klausul pembebasan (klausula eksonerasi) yang terkandung dalam kontrak standar, dan apakah pembeli sebagian turut bersalah dalam menyebabkan kerusakan objek perjanjian sebagaimana yang didalilkan oleh pembeli. Menurut Mahkamah, dikenakannya Pasal 2:204 (2) Prinsip Hukum Kontrak Eropa, Pasal 2.20 dari Prinsip UNIDROIT pada kontrak standar yang dibuat oleh penjual tanaman instalasi tersebut dengan cara tidak menempatkan secara eksplisit istilah mengejutkan (surprising terms), serta didasarkan pada asumsi bahwa istilah itu menjadi bersifat mengejutkan karena tidak dalam penggunaan umum di sektor komersial yang relevan.

Ketentuan mengenai tanggung jawab pelaku usaha dalam Undang-Undang Perlindungan konsumen dinyatakan dalam Pasal 19 ayat (2), bahwa Ganti rugi dapat berupa pengembalian uang atau penggantian barang dan/atau jasa yang sejenis atau setara nilainya, perawatan kesehatan dan/atau pemberian santunan yang sesuai dengan ketentuan peraturan perundangundangan yang berlaku.

Sedangkan limitasi terhadap pertanggungjawaban pelaku usaha dituangkan dalam Pasal 19 ayat (5), bahwa ketentuan tidak berlaku apabila pelaku usaha dapat membuktikan kesalahan tersebut merupakan kesalahan konsumen. Di Indonesia sendiri, telah terdapat beberapa Putusan pengadilan tentang sengketa pelaksanaan kontrak baku, salah satunya yaitu putusan Mahkamah Agung Republik Indonesia Nomor 2078 K/Pdt/2009 antara Sumito Y. Viansyah (Penggugat) dengan PT. Securindo Packatama Indonesia (Tergugat) yang merujuk pada putusan Mahkamah Agung sebelumnya yaitu Putusan MA No. 1264 K/Pdt/2003 tanggal 14 Juli 2005 terkait adanya klausula eksonerasi yang dicetak di balik karcis atau kartu parkir.

Berdasarkan yurisprudensi, bahwa hubungan hukum antara pemilik kendaraan dengan pengusaha parkir adalah perjanjian penitipan, yang jika dihubungkan dengan Pasal 1365, 1366, 1367 BW data maka tergugat berkewajiban untuk menanggung kehilangan sepeda motor penggugat di tempat pengelolaan tergugat. Pengadilan pun menjatuhkan hukuman kepada Secure Parking untuk membayar ganti rugi materiil sebesar 60 juta rupiah dan non materiil 15 juta rupiah. Kemudian di Pengadilan Tinggi DKI Jakarta, Secure Parking tetap diputus melakukan perbuatan melanggar hukum. Namun Pengadilan Tinggi DKI menghapus hukuman terkait ganti rugi non materiil. Koordinator Yayasan Bina Konsumen Indonesia Hermina Suyono menilai putusan MA ini bisa di break down menjadi sebuah peraturan daerah oleh tiap pemerintah daerah (Ahmad Baidowi, Pengelola Parkir Harus Ganti Kendaraan Hilang, www.Seputar-Indonesia.Com/ Edisicetak/Content/View/340814/). Demikian pula dengan Putusan Mahkamah Agung Nomor 2078/K/ Pdt/2009 dari Kasasi yang diajukan oleh tergugat, turut menguatkan putusan sebelumnya di tingkat Pengadilan Tinggi DKI Jakarta yang memerintahkan Secure Parking membayar ganti rugi materiil sebesar 60 juta rupiah.

Beberapa Putusan Mahkamah Agung terkait dengan sengketa dalam penerapan kontrak adhesi di atas menunjukkan bahwa Mahkamah Agung telah memberi dukungan pada doktrin misbruik van omstandighegen dengan membatalkan suatu kontrak yang terjadi atas dasar penyalahgunaan keadaan. Putusan yang mendukung prinsip tersebut juga merupakan suatu upaya untuk memberikan kekuatan hukum terhadap pelanggaran Pasal 1338 ayat 3 BW yang menegaskan keharusan adanya unsur itikad baik (good faith) yang ditunjukkan kedua belah pihak yang berkontrak. 


\section{PENUTUP}

\section{Kesimpulan}

Karakteristik kontrak adhesi dalam transaksi bisnis komersial yang merupakan perjanjian yang telah distandarisasi isinya oleh salah satu pihak karena kedudukannya yang lebih mendominasi ataupun posisi yang lebih menentukan dalam hubungan berkontrak dengan mitra berkontraknya, merupakan bentuk dari perwujudan asas kebebasan berkontrak berdasarkan party authonomy. Namun, di sisi lain kedudukan kontrak adhesi juga membatasi keberlakuan asas kebebasan berkontrak itu sendiri, yaitu pada jenis kontrak adhesi yang secara otomatis berlaku (take it or leave it) tanpa adanya kesempatan untuk menegosiasikan isi kontrak.

Kesepakatan merupakan hal yang sangat penting karena dengan terbentuknya konsensualisme kontrak berlaku dan mengikat bagi para pihak. Namun, kesepakatan yang diberikan oleh pihak yang mengikuti kontrak adhesi merupakan kesepakatan yang didasari adanya cacat kehendak terlebih di dalam kontrak adhesi tersebut terdapat klausula eksonerasi sehingga kontrak tersebut mengandung penyalahgunaan keadaan (misbruik van omstandigheden) atau misuse dengan itikad buruk (bad faith) yang dilakukan oleh pihak yang membuat kontrak adhesi. Beberapa putusan atau pun yurisprudensi dari Mahkamah Agung baik di Indonesia maupun Belanda telah memberikan dukungan pada prinsip misbruik van omstandigheden ini.

\section{Rekomendasi}

Keberadaan kontrak baku, kontrak adhesi, tentu saja dapat memicu permasalahan lebih lanjut walaupun ada kalanya kontrak tersebut tidak menimbulkan suatu permasalahan karena dinilai adil kedudukan para pihaknya walau kontrak tersebut hanya dibuat oleh satu pihak saja. Permasalahan dalam kontrak adhesi selain karena adanya penyalahgunaan kedudukan yang lebih mendominasi, juga terdapatnya klausula eksonerasi. Bagaimanapun perihal penyalahgunaan keadaan dalam kontrak adhesi sungguh merupakan masalah yang pelik, karena diperlukan adanya pembuktian itikad baik atau buruk dari pihak dalam kontrak. Pengaturan hukum di luar hukum Indonesia dan doktrin misbruik van omstanddigheden sudah selayaknya dituangkan dalam suatu perundang-undangan. Karena sejatinya perlindungan hukum bagi pihak yang lemah dalam kontrak adhesi ini hanyalah melalui putusan hakim, oleh karena itu diperlukan ketelitian dan ketajaman analisa dengan pertimbangan aturan-aturan yang ada bagi hakim dalam menilai persoalan yang cukup pelik ini.

\section{DAFTAR PUSTAKA \\ Buku:}

Hernoko, Agus Yudha. 2010. Hukum Perjanjian Asas Proporsionalitas dalam Kontrak Komersial. Cet.

2. Jakarta: Kencana.

2008. Hukum perikatan. Surabaya: Bahan Ajar Fakultas Hukum Universitas Airlangga.

Simanjuntak, Emmy Pangaribuan. 2010. Perbandingan Beberapa Prinsip UNIDROIT 2004 dari Prinsip CISG. Yogyakarta: Bahan Ajar MHB UGM.

Simanjuntak, Ricardo. 2011. Teknik Perancangan Kontrak Bisnis. Cet. 2. Jakarta: Kontan Publishing.

Sjahdeini, Sutan Remy. 1983. Kebebasan Berkontrak dan Perlindungan yang Seimbang bagi Para Pihak dalam Perjanjian Kredit Bank di Indonesia. Jakarta: Institut Bankir Indonesia.

Subekti. 1990. Hukum Perjanjian. Cet. 12. Jakarta: Intermasa.

\section{Peraturan Perundangan-undangan:}

Undang-Dasar Republik Indonesia Tahun 1945.

Undang-Undang Nomor 8 Tahun 1999 tentang Perlindungan Konsumen.

Undang-Undang Nomor 12 Tahun 2011 tentang Pembentukan Peraturan Perundang-undangan. Burgerlijk Weetbook.

The third edition of the UNIDROIT Principles of International Commercial Contracts (UNIDROIT Principles 2010).

Tesis:

Adams, John. 2004. "Digital Age Standard Form Contracts Under Australian Law: "Wrap" Agreements, Exclusive Jurisdiction, and Binding Arbitration Clauses". Thesis. Pacific Rim Law \& Policy Journal Association.

\section{Website:}

http://unilex.info/case.cfm?id=1538 diakses tanggal 18 September 2012.

http://lexmecatoria.org diakses tanggal 11 September 2012.

http://legislation.gov.uk diakses tanggal 12 September 2012. 